\title{
Generation Z Attitudes towards Internet Usage for E-Commerce in Selangor, Malaysia
}

\author{
Ilangovan Perumal, Azween Abdullah, Muthaloo Subramaniam, Ramesh Kumar Moona Haji \\ Mohamed, Sugumaran Selladurai
}

\begin{abstract}
This study examines a study of Generation $Z$ attitudes toward internet usage for E-commerce in selangor, Malaysia. The specific factors studied were attitude toward internet usage; computer literacy; consumer lifestyle; and perceived ease of use. This study drew on a total sample size of 150 respondents and distributed questionnaires to collect the data. The collected data was analyzed using the Statistical Package for Social Science (SPSS) software, Version 23. All the results and findings based on the data collected were further summarized, including Cronbach's Alpha, descriptive statistics, correlation analysis, and multiple regression. The results indicate that the independent variables have a significant positive relationship with the dependent variables in this study. This study could be beneficial to Generation $Z$ because it increases our understanding of the factors of E-commerce.
\end{abstract}

Keywords: E-Commerce, Attitude, Computer Literacy, Consumer Lifestyle and Perceived Ease of Use

\section{INTRODUCTION}

In the contemporary world, businesses are reaching new heights of excellence. The business environment has been consciously going through this change with variation over many dynamics. The $21^{\text {st }}$ century is viewed as the century of increased technological innovations and their use in practical life. The emergence of internet facilities in the U.S. in the 1980s marks the beginning of these changes in the business environment. Later on, the U.S. facility revolutionized the work and gave it the status of a global village. Today, most research studies refer to it as a global theater (Chang et al., 2013).

Revised Manuscript Received on 14 September, 2019.

* Correspondence Author

Ilangovan Perumal*, Faculty of Business, Accounting and Management SEGi University, Kota Damansara, Malaysia. Email: ilangovan@segi.edu.my

Azween Abdullah, School of Computing and IT, Faculty of Innovation and Technology, Taylor's University, Subang Jaya, Malaysia. Email: azween.abdullah@taylors.edu.my

Muthaloo Subramaniam, Faculty of Business, Accounting and Management, SEGi University, Kota Damansara, Malaysia. Email: muthaloo@segi.edu.my

Ramesh Kumar Moona Haji Mohamed, Faculty of Business and Finance, University Tunku Abdul Rahman (UTAR), Kota Damansara, Malaysia. Email: rameshk@utar.edu.my

Sugumaran Selladurai, Faculty of Business, Accounting and Management, SEGi University, Kota Damansara, Malaysia. Email: sugumaran@segi.edu.my
The business world has progressed toward branchless business operations where the presence of a physical shop is viewed as useless based on the modern technology that allows computers and the internet to take its place. Today, most businesses have changed their daily operations by upgrading traditional systems to e-commerce. E-commerce is a cyberspace-based process which is designed to arrange the flow of the goods from one unit or business to another actor or individual who needs that service or product (Houliez and Gamble, 2012). The flow of goods and services through internet channels gave the rise to the term e-commerce. As a result, businesses have become keenly interested in the establishment of such channels, mainly because these channels can reduce if not eliminate the amount of manpower needed for ordinary business operations. The emergence of e-commerce and its adoption by many customers to fulfill basic benchmarking necessitated the need to analyze Generation $\mathrm{Z}$ attitudes toward internet usage for e-commerce in Kota Damansara, Malaysia, because the same city holds a particular position for this business and its use (Hussin and Noor, 2013). Today, e-commerce has become the most developed trend based on businesses competing against each other in terms of maximum customer facilitation (Seng and Wei, 2015). The rapid growth of innovation and technological development has been adopted by many businesses to gain access to their diversified target markets and leading toward the globalization of different businesses (Ho and Chau, 2013). E-Commerce eliminated the existing boundaries, allowing them to thrive.

\section{LITERATURE REVIEW}

\section{A. E-Commerce}

E-Commerce is considered one of the factors which has altered the fate of the business environment. Nowadays, e-commerce in Malaysia is accepted by all generations. Malaysian consumers have the highest mobile and online usage rates; they are more reliant on the internet than many other countries. Malaysia has a strong online penetration rate of approximately $66 \%$ and around 20 million online users (Manjur, 2015). In contemporary times, e-commerce in business has changed the traditional look of business operations (Shih et al., 2013). Managers and business practitioners are accustomed to 


\section{Generation Z Attitudes towards Internet Usage for E-Commerce in Selangor, Malaysia}

adhering to modern technologies that can be used to facilitate the business processes through the addition of modern technological tools. This business process re-engineering has changed the overall look of how businesses work, and these developments have initiated the use of e-commerce in many business arenas.

Many authors have contributed their efforts to define e-commerce as an electronic means of doing business; more specifically, the selling of products and services using internet technology (Peddibhotla, 2013). E-Commerce also refers to the electronic means of conducting business through an internet facility.Researchers have examined e-commerce in diversified dimensions to better understand the adaptability of specific technologies. The increased trend of development within specific areas of conducting business has caused researchers to contribute their efforts to determine its relationship with other variables (Kwon and Sung, 2013). One author stated that due to the increase in globalization, e-commerce is one of the most useful means of doing business across various boundaries, especially for businesses that cannot afford to penetrate the international market. This author further added that because of e-commerce, market competition has been observed to be continuously directed toward increase and growth (Ajmal and Asin, 2015). This author also stated that e-commerce resulted in an improvement in product and service quality based on the competition being directed toward a peak and the diversified customer standards for judging product and service quality (Shih et al., 2013).

\section{B. Literature Review of the Variable Attitude toward Internet}

Today, nearly everything humans do involves computers, technology, and the internet. For Generation Z, these are not only useful tools, but a way of life (Mastroianni, 2016). Attitudes toward internet usage refer to individual acceptance of the using the internet for various purposes (Riedl et al., 2013). The development of technology and the availability of the internet facility for Generation $\mathrm{Z}$ has created different impacts for individual demands. One author stated that because of the readily available technology, differences are observed in attitudes toward its adoption. The author stated that Generation Z cannot consider executing anything without using the internet (Hussin and Noor, 2013). Generation Z's dependence on the internet for information seeking has also directed the business sector's focus toward developing their means of interaction through the internet using social media, web pages, etc.

Generation $\mathrm{Z}$ is unique and distinct from the previous generation. Generation $\mathrm{Z}$ grew up with the rapid development of emerging technology innovations and the explosion of information. One of the most significant differences is the need to always be connected. Generation Z keeps in touch with everyone who fully utilizes advanced internet tools such as instant messaging and social media. In particular, WeChat, Weibo, Twitter, and Facebook are most popular, as well as Instagram (Mastroianni, 2016). Researchers believe that a person's attitude develops according to his or her surroundings. The development of technology and the high dependence by individuals on the internet has resulted in increased demand from all sectors to consider it the primary medium of communication and interaction for new generations (Gangeshwer, 2013). The author stated that differences are observed within the ways the internet facility is used because of differences observed in how businesses operate. Arcand and Nantel (2012) added that the individual attitudes toward internet use have been observed to be highly developed and to have a large impact on internet demand for people seeking maximum convenience and ease in their daily routines. As stated by the experts, despite the differences among the new generation's demands and needs, they share the common demand for basic facilities to be made part of all organization strategies. The author stated that attitudes toward the internet have directed the attention of the business sector to solve problems in managing individual demand and directing the maximum possible effort to acquiring favorable outcomes (Kabango and Asa, 2015).

\section{Computer Literacy}

Computer literacy is defined as awareness and knowledge about the usage and technical aspects of computers (Shih et al., 2013). People in the current era are directed to consider computers as basic equipment for education, in the business profession, and for day-to-day routines. It is nearly impossible for an individual to seek better outcomes in anything without understanding how to use a computer nowadays (Gangeshwer, 2013). The author stated that computer literacy means having the knowledge of how to use it; expertise level varies per individual need. The author further added that without a computer nowadays, any task is impossible. The transformation of manual work completely into digital means has resulted in a higher demand for computer literacy among individuals (Eid, 2011). The author stated that awareness or knowledge about computers is not only linked with an individual's use for shopping and other personal things, but for one's professional career, it is one of the most basic needs. Computer literacy and the awareness of how to manage things using a computer is a most basic and important need (Alqahtani et al., 2013).

Arcand and Nantel (2012) stated that computer literacy has not remained a special skill among individuals as it once had been because the upcoming generations have experienced the availability of all such technologies since birth. The author stated that because the internet is readily available to newer generations, they are directed to learn and do things using it from childhood; they avoid the manual struggle experienced by many older people (Seng and Wei, 2015). Chang et al. (2013) stated that changes within the technology and demand within the external environment have created a high level of demand for internet access. Research conducted in 2015 at the National University of Malaysia reveals that respondents have a high rate of internet access and a high level of computer literacy as well as being able to operate the latest 
computer technologies and internet tools (Ahmad, 2015).

\section{Consumer Lifestyle}

The consumer lifestyle is defined as an individual's adopted ways of living and standards (De Vries et al., 2012). Malaysian consumers are increasingly going online to shop; online sales reached more than RM 1.2 billion in 2013 (Manjur, 2015). These changes within the environment and its surroundings are directing people toward adopting new, different, and unique things. The author stated that these continuous and rapid changes in the surroundings have created significant changes to individual lifestyles. Riedl et al. (2013) further added that because of the higher level of dependency on different basic facilities, consumers are directed toward continuous changes and adopting of new things. The author also stated that as consumer lifestyle changes, so do the ways of doing things. The author stated that these changes are basically incurred because of the continuous changes taking place in the availability of products and services, the advancement of technology, and changes in buying power and behaviors (Hajli, 2013). The author stated that consumer lifestyle has a direct and significant impact on the corporate sector relating to reconsidering ways of doing businesses and bringing innovative and creative means of managing things to market (Ken Research, 2014).

The author found that these lifestyle changes are resulting in the creation of different kinds of changes in outcomes being drawn from the acquired results. The situation has been observed to change over a period of time because of the spontaneous changes occurring in the market. Consumers are observing changes in their demands and needs, resulting in higher demand for more concise products and services that align their required features with the outcomes they want (Weisberg et al., 2011). The author stated that because of the changes taking place in consumer lifestyle, the corporate sector has been directed toward different changes and serious consequences. Individuals have faced problems based on the lack of defined lifestyle demands, and individuals are facing issues in managing their assigned tasks (Ingham et al., 2014). These are the issues faced in determining the highly unpredictable consumer lifestyles, which has resulted in different levels of success and failure in product and service offerings within the market (Wang et al., 2012).

\section{E. Perceived ease of use}

Perceived ease of use is defined as a person's perception based on their personal experiences or on other opinions about the ease of using a specific thing (Shih et al., 2013). The author stated that nowadays people are looking for the maximum benefit and advantage to avoid problems and inconveniences in using a specific product or service. Consumer demand is observed to be directed toward setting different standards or measurement criteria so that they may select the best available option (Eid, 2011). Differences observed in individual perception are related to the ease or convenience of using a specific product or service. The author stated that perceived ease of use reflects a significant relationship with consumer buying behavior as well as willingness to accept new things (Wang et al., 2012).

Luthfi (2014) found that perceived ease of use had a significantly positive effect on Generation $\mathrm{Z}$ attitudes toward internet usage for e-commerce in Malaysia. Researchers stated that perceived ease of use refers mainly to personal experience or individual perception. Individuals are observed to be affected through what facts have been stated by people regarding a specific service or product (Gangeshwer, 2013). These changes are observed to take place within one's perception developed according to the changes taking place in the individual's surrounding facilities (Chang et al., 2013). The author stated that perceived ease of use helps businesses approach customers in the best possible ways to ensure that desired outcomes and better market results are achieved. Perceived ease of use has been observed to reflect a significant and high level of association with the demand of products and services being offered within the market.

E-Commerce was introduced based on the concept that customers can receive desired products on their door steps without any delay or hassle. The main agenda for businesses using e-commerce is to approach customers instead of waiting for customers to approach them. The goal of e-commerce is to ensure that a business is providing maximum ease to customers by approaching them and fulfilling their demands and needs (Rezai et al., 2013).

\section{METHODOLOGY}

\section{A. Research instrument/measurement}

A quantitative research method is applied in this study. Questionnaires were distributed as a data gathering method. Besides the low cost associated with this method, it allows the fastest responses from the targeted audience. The structure is designed according to the Likert scale, 5-point format. The design will be as follows: 1- Strongly Disagree; 2- Disagree; 3- Neutral; 4- Agree; and 5- Strongly Agree. Each of the variables will be evaluated using six questions. Analysis will be conducted descriptively and SPSS Version 23.0 will be used to study correlative analysis.

\section{B. Pilot study}

A pilot study was conducted with Generation $\mathrm{Z}$ prior to the data collection. The purpose of the pilot study is to ensure that the questionnaire instructions and content are clear and understood by the respondents, as well as to test its reliability and validity. After the pilot test, Cronbach's Alpha value will be used to examine the pilot test's reliability. Amendments will be made to the questionnaires based on respondents' suggestions. 


\section{Generation Z Attitudes towards Internet Usage for E-Commerce in Selangor, Malaysia}

\section{DATA ANALYSIS}

\section{A. Correlation Analysis}

Table 4.1-Correlation Analysis

\begin{tabular}{|c|c|c|c|c|c|c|}
\hline & & $\begin{array}{l}\text { E- } \\
\text { Commerce }\end{array}$ & \begin{tabular}{|l} 
Attitude \\
toward \\
Internet \\
Usage
\end{tabular} & $\begin{array}{l}\text { Computer } \\
\text { Literacy }\end{array}$ & $\begin{array}{l}\text { Consumer } \\
\text { Lifestyle }\end{array}$ & $\begin{array}{l}\text { Perceived } \\
\text { Ease of Use }\end{array}$ \\
\hline E-Commerce & $\begin{array}{l}\text { Pearson Correlation } \\
\text { Sig. (2-tailed) } \\
\text { N }\end{array}$ & 150 & $\begin{array}{l}.528^{*} \\
.000 \\
150\end{array}$ & $\begin{array}{l}.603^{* *} \\
.000 \\
150\end{array}$ & $\begin{array}{l}.679^{* *} \\
.001 \\
150\end{array}$ & $\begin{array}{l}.640^{* *} \\
.000 \\
150\end{array}$ \\
\hline $\begin{array}{l}\text { Attitude } \\
\text { toward } \\
\text { Internet } \\
\text { Usage }\end{array}$ & $\begin{array}{l}\text { Pearson Correlation } \\
\text { Sig. (2-tailed) } \\
\text { N }\end{array}$ & $\begin{array}{l}.528^{* *} \\
.000 \\
150\end{array}$ & 150 & $\begin{array}{l}.677^{*} \\
.000 \\
150\end{array}$ & $\begin{array}{l}.580^{* *} \\
.000\end{array}$ & $\begin{array}{l}.543^{*} \\
.000 \\
150\end{array}$ \\
\hline $\begin{array}{l}\text { Computer } \\
\text { Literacy }\end{array}$ & $\begin{array}{l}\text { Pearson Correlation } \\
\text { Sig. (2-tailed) } \\
\mathrm{N}\end{array}$ & $\begin{array}{l}.603^{* *} \\
.000 \\
150\end{array}$ & $\begin{array}{l}.677^{*} \\
.000 \\
150\end{array}$ & 150 & $\begin{array}{l}.509^{* *} \\
.000 \\
150\end{array}$ & $\begin{array}{l}.575^{*} \\
.000 \\
150\end{array}$ \\
\hline $\begin{array}{l}\text { Consumer } \\
\text { Lifestyle }\end{array}$ & $\begin{array}{l}\text { Pearson Correlation } \\
\text { Sig. (2-tailed) } \\
\text { N }\end{array}$ & $\begin{array}{l}.679^{* *} \\
.001 \\
150\end{array}$ & $\begin{array}{l}.580^{* *} \\
.000 \\
150\end{array}$ & $\begin{array}{l}.509^{* *} \\
.000 \\
150\end{array}$ & 150 & $\begin{array}{l}.611^{*} \\
.000 \\
150\end{array}$ \\
\hline
\end{tabular}

Table 4.1 shows that the value of Pearson Correlation $r$ Between E-Commerce and Attitude toward internet usage is 0.528 with a significance of 000 at the $1 \%$ Level $(<p=0.01)$, which shows a positive correlation between E-Commerce and Attitude toward internet usage. The value of Pearson Correlation $r$ Between E-Commerce and Computer Literacy is 0.603 with a significance of 000 at the $1 \%$ Level $(<\mathrm{p}=0.01)$, which shows a positive correlation between E-Commerce and Computer Literacy. The value of Pearson Correlation r Between E-Commerce and Consumer Lifestyle is 0.679 with a significance of 000 at the $1 \%$ Level $(<\mathrm{p}=0.01)$, which shows a positive correlation between E-Commerce and Consumer Lifestyle. The value of Pearson Correlation $r$ Between E-Commerce and Perceived Ease of Use is 0.640 with a significance of 000 at the $1 \%$ Level $(<p=0.01)$, which shows a positive correlation between E-Commerce and Perceived Ease of Use.

\section{B. Multiple Regression Analysis}

Table4.2-Model Summary

\begin{tabular}{|l|l|l|l|l|}
\hline Model & $R$ & R Square & Adjusted R Square & Std. Error of the Estimate \\
\hline 1 & $.552^{\mathrm{a}}$ & .304 & .285 & 3.07568 \\
\hline
\end{tabular}

- Predictors: (Constant), Attitude toward Internet Usage, Computer Literacy, Consumer Lifestyle, Perceived Ease of Use

\section{- Dependent variable: E-Commerce}

The Model Summary is shown in Table 4.2, which shows the value of $\mathrm{R}$ square that is .304 or $30.4 \%$. This means that $30.4 \%$ of the total variance in independent variables is explained, while the other $69.6 \%$ is subjected because of errors.

\section{ANOVA}

Table 4.3-ANOVA

\begin{tabular}{|c|c|c|c|c|c|}
\hline moset & Simat Spaven & a & Hean Squar & $f$ & s.9 \\
\hline Regonition & 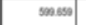 & & 102915 & 15800 & \\
\hline Revisuar & 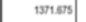 & 145 & 2000 & & \\
\hline Tros & | & 199 & & & \\
\hline
\end{tabular}

- Predictors: (Constant), Attitude toward Internet Usage, Computer Literacy, Consumer Lifestyle, Perceived Ease of Use

- Dependent variable: E-Commerce

Table 4.3 shows the value of Anova. The Anova summary shows the level of significance at 0.000 that demonstrates the fitness of the model and a reasonably good outcome. The value of $F$ is 15.848 , which shows the variance between independent and dependent variables.

\section{Coefficient Test}

Table 4.4-Coefficients

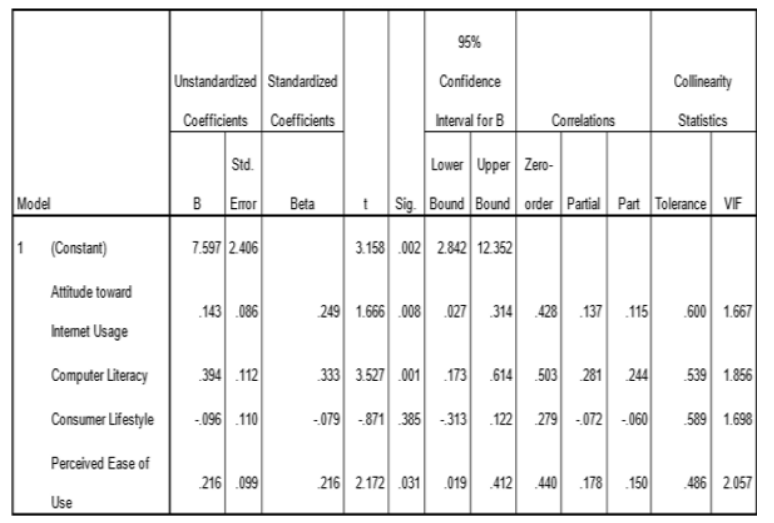

- Dependent Variable: E-Commerce

Table 4.4 shows the value of coefficients derived from multiple regression analysis. Table 4.4 represents that the value of VIF for all independent variables is less than 10, and that no multicollinearity relationship is seen among variables. The level of significance should be less than .05 , and this table also shows the value of significance is lower than .05 for computer literacy, attitude toward internet usage, and perceived ease of use, showing its power to influence e-commerce in Generation Z. The consumer lifestyle has a higher value for significance than .05 The relationship between the variables could be denoted as $t$ he formula below:

$X_{0} \beta_{0}=c+X_{1} \beta_{1}+X_{2} \beta_{2}+X_{a} \beta_{a}+X_{4} \beta_{4}+e$

And the relationship could be redefined as

$$
\mathrm{EC}=7.597+0.143 \mathrm{AIU}+0.394 \mathrm{COL}+(-0.096) \mathrm{CL}+
$$

$$
0.216 \mathrm{PEU}
$$

$\mathrm{EC}=\mathrm{E}-\mathrm{Commerce}$

$\mathrm{AIU}=$ Attitude toward Internet Usage

$\mathrm{COL}=$ Computer Literacy

$\mathrm{CL}=$ Consumer Lifestyle

PEU $=$ Perceived Ease of Use

$\mathrm{c}=$ Constant

$\mathrm{e}=$ Error 


\section{DISCUSSION AND CONCLUSION}

The research was conducted using four independent variables of attitude toward computer literacy, consumer lifestyle, and perceived ease of use that indirectly influence e-commerce. All of these factors are sufficiently influential on the research results, but the researcher also found various influential independent variables such as perceived trust, perceived benefit, and perceived risk. These independent variables are also associated with e-commerce.

\section{A. Perceived trust}

Perceived trust is a combination of attitudes that can perform in uncertain times and dynamic situations. Generation $\mathrm{Z}$ represents open minded people who tend to trust in the words as described according to e-commerce behaviors (Garbarino, 1999).

\section{B. Perceived benefit}

For Generation Z, perceived benefits tend to be associated more with positive responsiveness than with a derived threat toward e-commerce because this generation's attitude plays a vital role in satisfaction level as it is influenced by e-commerce. As much as the perceived benefit is associated with them, more people can be engaged with e-commerce and will tend to explore a positive relationship with it (M.J, 2002).

\section{Perceived risk}

Perceived risk is associated with unpleasant factors of outcome regarding product, price, or quality according to customer perception that can influence e-commerce. This illustrates the behavioral aspects of Generation $\mathrm{Z}$ relating to risk factor (Forsythe, 2003). All the other described variables tend to explore the e-commerce information as being influenced by perceived trust, benefit, and risk. It is recommended that further research of e-commerce as it relates to Generation $\mathrm{Z}$ should be conducted on these variables.

It is also recommended that for conducting more research studies, the time period should be longer than the almost three months achieved here. This is because using a sufficient time period will generate more accurate and qualitative research results. It is also recommended that the questionnaire would not only be distributed to the current area of research but also it among Malaysia's other states; i.e., Kepong, Petaling, Penang, and Johor, because different societal groups tend to have different associations for the prescribed variables. More variety will create more effective and high-quality responses for the area of research. Societies also differ according to culture, norms, values, and thoughts about e-commerce. It would be good to discover how much different societies tend to encourage internet use, and the researcher would learn more about Malaysian e-commerce.

The research questionnaires were distributed by hand in English to achieve the exact meaning the researcher intended. The research was conducted with a small sample size of 150 , but it is recommended that future research be conducted with a larger sample size of the respondents from the various states of Malaysia. For further proceedings, the researcher should have to establish a relationship with respondents in order to perceive the influences of e-commerce on their personal lives and how they benefit from it. Because most of Generation $\mathrm{Z}$ are more attached to technologies, they tend to explore more work opportunities that are engaged with them.

\section{REFERENCES}

1. Ahmad, A. R. (2015). Computer Literacy www.wseas.us/e-library/ conferences/ 2015Program: A Study of Adult Student Perspectives. Retrieved from: http:// /Malaysia/EDU/EDU-02.pdf

2. Ajmal, F., Asin, N. (2015). "Electronic commerce adoption in Malaysia: An empirical study of small and medium-sized enterprises (SMES)." International Journal of Advances in Electronics and Computer Science. 2(5): 5-9

3. Alqahtani, M. A., Al-Badi, A. H., \& Mayhew, P. J. (2013). Exploratory Study of M-Transaction: User's Perspectives. The Electronic Journal of Information Systems in Developing Countries, 60.Anthopoulos

4. Arcand, M., Nantel, J. (2012). Uncovering the nature of information processing of men and women online: The comparison of two models using the Think- Aloud Method.Journal of Theoretical and Applied Electronic Commerce Research 7(2): 106-120

5. Chang, A., Hsieh, SH., Lin, F. (2013). Personality traits that lead members of online brand communities to participate in information sending and receiving. International Journal of Electronic Commerce 17(3): 37-62.

6. De Vries, L., Gensler, S. 8c Leeflang, E. S. H. (2012). Popularity of brand posts on brand fan pages: An investigation of the effects of social media marketing. Journal of Interactive Marketing. 26(2): 83-91.

7. Eid, M. I. (2011). Determinants of e-commerce customer satisfaction, trust, and loyalty in Saudi Arabia. Journal of Electronic Commerce Research, 12(1), 78-93.

8. Forsythe, S. A. (2003). Consumer Patronage and Risk Perceptions in Internet Shopping. Journals of business research.

9. Gangeshwer, D. (2013). E-Commerce or internet marketing: A business review from Indian context. International Journal of u- and e- Service, Science and Technology. 6(6): 187-194

10. Garbarino, E. a. (1999). The different roles of satisfaction, trust and commitment in customer relationships. Journals of Marketing, 63: $70-87$.

11. Hajli, M. (2013). A research framework for social commerce adoption Information Management \& Computer Security. 21(3): 144-154.

12. Ho SY, Chau PYK (2013) The effects of location personalization on integrity trust and integrity distrust in mobile merchants. International Journal of Electronic Commerce 17 (4): 39-72.

13. Houliez C, Gamble E (2012) Augmented focus groups: On leveraging the peculiarities of online virtual worlds when conducting in-world focus groups. Journal of Theoretical and Applied Electronic Commerce Research 7 (2): 31-51

14. Hussin, H., Noor, R. (2013). "INNOVATING BUSINESS THROUGH E-COMMERCE: EXPLORING THE WILLINGNESS OF MALAYSIAN SMEs." The Second International Conference on Innovations in IT (IIT'05)

15. Ingham J., Cadieux J. and Berrada A.M. (2014). E-shopping acceptance: A qualitative and meta-analytic review. Information \& Management. 52, 44-60.

16. Kabango, C., Asa, A. (2015). Factors influencing e-commerce development: Implications for the developing countries. International Journal of Innovation and Economic Development. 1(1): 59-66.

17. Ken Research (2014). Malaysia e-commerce industry outlook to 2019Driven by internet penetration and mobile access devices. Malaysia

18. Kwon O, Sung Y (2013) Shifting selves and product reviews: How the effects of product reviews vary depending on the self-views and self-regulatory goals of consumers. International Journal of Electronic Commerce 17 (1): 59-82.

19. Luthfi, H.M. (2014). A study of generation Y attitude towards usage of internet for e-commerce in MSC

landmark, Kuala Lumpur \& 


\section{Generation Z Attitudes towards Internet Usage for E-Commerce in Selangor, Malaysia}

Selangor state. Retrieved from: http://etd.uum.edu.my/4096/

20. M.J, E. (2002). Diffusion of E-Commerce: An Analysis of the Adoption of four E-Commerce Activities.

21. Manjur, R. (2015).E-commerce set to boom in Malaysia. Retrieved from:http://www.marketing-interactive.com/e-commerce-next-big-boo m-malaysia/

22. Mastroianni, B. (2016). How Generation $\mathrm{Z}$ is changing the tech world. Retrieved from: http://www.cbsnews.com/news/social-media-fuels-a-change-in-generati ons-with-the-rise-of-gen-z/

23. Peddibhotla N (2013) How individuals choose topics to contribute at an online context? Electronic Markets 23 (3): 241-250

24. Rezai, G., Mohamed, Z., Shamsudin, M., Zahran, M. (2013). Effect of Consumer Demographic Factors on Purchasing Herbal Products Online in Malaysia. International Journal of Social, Education, Economics and Management Engineering, 7(8), 1108-1114

25. Riedl C, Blohm I, Leimeister JM, Krcmar H (2013) The effect of rating scales on decision quality and user attitudes in online innovation communities. International Journal of Electronic Commerce 17 (3): 7-36.

26. Seng, L., Wei, C. (2015). "AN EMPIRICAL STUDY ON E-COMMERCE TRUST OF MALAYSIAN CONSUMERS.” International Journal of Economics, Commerce and Management. III(7): 368-382.

27. Shih H, Lai K, Cheng TCE (2013). Informational and relational influences on electronic word of mouth: An empirical study of an online consumer discussion forum. International Journal of Electronic Commerce 17 (4): 137-166.

28. Wang, X., Yu, C., Wei, Y. (2012). Social media peer communication and impacts on purchase intentions: a consumer socialization framework. Journal of Interactive Marketing. 26 (4): 198-208.

29. Weisberg, J., Te'eni, D., Arman, L. (2011). Past purchase and intention to purchase in e-commerce: the mediation of social presence and trust. Internet Research. 21 (1): 82-96

\section{AUTHORS PROFILE}

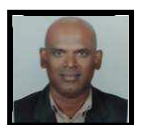

Mr. Ilangovan Perumal is a Senior Lecturer Faculty of Business, Accounting and Management, Segi University, Kota Damansara. His expertise is in the areas of management information systems, ecommerce, computer science educational systems and IT in business. He has taught various computer related subjects for various background of students, locally and internationally ranging from certificate to undergraduate level. He has published few papers in the various computer and business related journals. Mr. Ilangovan Perumal holds a Master degree in Computer Science from University of Malaya and currently pursuing Phd in IT.

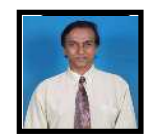

Associate Professor Dr. Azween Abdullah has been contributing to research, teaching, consulting and in administrative services to the institutions that he has been working for thus far. He is a professional development alumni of Stanford University and MIT and his work experience includes thirty years as an academic in institutions of higher learning and as director of research and academic affairs at two institutions of higher learning, vice-president for educational consultancy services, fifteen years in commercial companies as Software Engineer, Systems Analyst and as a computer software developer and IT/MIS consultancy and training. Dr. Azween Abdullah has several patents under his name and been actively serving as expert reviewer and editorial board member for several high impact technical journals. Prior to joining Taylors University, Dr. Azween Abdullah served as faculty member at Monash University, Malaysia and Petronas University of Technology. He served as an adjunct research professor at the Malaysian University of Science and Technology and currently serves as the adjunct professor at SEGi University. He has guided and produced more than twenty post-graduate students. He is a fellow of the British Computer Society and senior member of IEEE. Dr. Azween Abdullah's general research interests are in the areas of cyber security and trustworthy computing, formal models of computation, and graph analytics in cyber security. He has been consulting for some technology companies in content development and has done research on emerging areas of networked and quantum security. He has been involved with a number of government and semi-government organizations in Malaysia in the role of external consultant and currently works with several government linked companies and industries to promote cyber security capacity development. He has also published more than 150 publications in various technical journals and conference proceedings and has given technical talks in a number of key international conferences, industry summits and forums.
Dr. Muthaloo Subramaniam is currently a Senior Lecturer at the Faculty of Business, Accounting and Management (FOBAM) at SEGi University, Malaysia for more than 8 years. Numerous positions were held during and before joining SEGi University. Among others, he was a Deputy Head of FOBAM, Faculty Manager for Academic (Dean) of Faculty of Business Management and Globalisation, Limkokwing University of Creative Technology as well Student Advisor of Partner Programmes of Anglia Ruskin University and Head of Accounting Programmes Department at YPC International College (Kolej Teknologi YPC iT-Web). He holds a PhD in Management from SEGi University, Master degree in Management Majoring IT from University Putra Malaysia and Bachelor's degree in Accounting (Hons) from University of Malaya. He is a well experienced accounting, IT and business professional with over 19 years of experience in the corporate and higher education. He possess experience in corporate setting on IT and accounting related jobs before fully involved in teaching both local and international programmes and research. As to date, he has published several papers in peer reviewed journals. His versatility prevails at all time. In a professional attachment, he is an Associate Member of Malaysian Institute of Accountants, Associate Member of Chartered Tax Institute of Malaysia, Member of Malaysian Institute of Management and Life Member of Malaysian Human Resource Management.

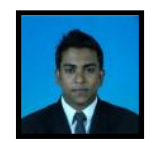

Dr. Ramesh Kumar Moona Haji currently is an Assistant Professor at the Faculty of Business \& Finance, University Tunku Abdul Rahman (UTAR) Malaysia. He received his Master's degree in MBA from the University of Utara Malaysia (UUM). Graduated Honours Bachelor degree, major in Management and minor in Political Science from the University Science of Malaysia. He pursued his Ph.D. from USM in Human Resource Management field. He has more than 12 years of progressive Human Resource Executives experience and 12 years of teaching experience.

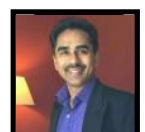

. Dr. Sugumaran Selladurai currently serves as a Dean, Faculty of Business, Accounting \& Management, SEGi University. Dr. Sugumaran attained his Doctorate in Business Administration from University Utara Malaysia and Master in Business Administration major in Marketing Management from University of Wales, U.K and Bachelor of Accountancy from University of Bolton, U.K. He has more than 23 years of experience in the education industry, which includes regulatory, product development, operation and management. He plays a pivotal role in transforming the largest Faculty of Business, Accounting and Management into the most profitable unit in SEGi University. Apart from his leadership role at the faculty, he is also involved in research and development, focusing in the fields of Strategic Planning, Corporate Social Reporting and Active Teaching and Learning. He has published number of articles including SCOPUS indexed journals. 